\title{
Goal Programming Techniques for the Selection of Optimal Syllabus to Improve Education System
}

\author{
Kumari Surbhi ${ }^{1 *}$, Rajesh Kumar Tiwari ${ }^{2}$ \\ ${ }^{1,2}$ Department of Mathematics, Binod Bihari Mahto Koylanchal University, Dhanbad, India
}

\begin{abstract}
This research paper totally focused on improving the complexity of decision making on multiple objectives such as selection of subjects, area of study for better future, Industrial demands, and educational support in the selected area of job. These are the objectives faced by parents, students as well as teachers/professors. Education is the most powerful weapon for every country. Quality of education comes with outcome based study and collaboration with the industries. Here, the complexities in the system of decision making in setting up the optimal syllabus is solved by multiple objective programing called goal programming.
\end{abstract}

Keywords: Decision making, Education system, Goal programming, Multiple objective.

\section{Introduction}

Goal programming was first used by Charnes, Cooper and Ferguson in 1955, for optimal estimation of executive compensation by linear programming. The actual name was first appeared in 1961 by Charnes and Cooper, for management models and industrial applications of linear programming (O.R. theory and application by J. K. Sharma). The major strength of goal programming is its ease of use and simplicity, due to which it contains large number of application in every field. Goal programming is branch of multiple optimization, which in turn is a branch of multiple criteria decision making (MCDM) [SKalavathy]. In this paper we are going to solve the complexities and challenges comes in setting up optimal syllabus according to the industrial demands with the help of weighted goal programming method introduced by Charnes and Cooper in 1977. and setup a syllabus which helps the students to select the subject which also helps them in their selected work for future perspective and in the same way industries also get best person as per their requirements. It will also increase the economy and literacy rate of india and increases total capital income of the country and boost the overall education system.

\section{A. Goals to Improve Education System}

- Goal 1 (G1): To set the syllabus of higher classes according to the Industrial demand.
- Goal 2 (G2): To improve the quality of education by sharing inters personal skills between students.

- Goal 3 (G3): To provide quality of education and knowledge in various fields.

- Goal 4 (G4): To increase the number of men power in administration.

- Goal 5 (G5): To increase the number the school and colleges.

- Goal 6 (G6): To enhance students to focus on practical views of every topic.

- Goal 7 (G7): To increase the number of qualified professors/teachers.

B. Goal programming formulation to achieve the goals Let

- $\mathrm{X} 1=$ Number of professor required for each goals.

- $\mathrm{X} 2=$ Number of educational advisors required for each goals.

- P1: Maximize the underachievement of set up of new syllabus.

- D1: Minimize the over achievement of set up of new syllabus.

- P2: Maximize the underachievement of sharing of interpersonal skills.

- D2: Minimize the overachievement of sharing of interpersonal skills.

- P3: Minimize the overachievement of outcome based education.

- D3: Maximize the underachievement of outcome based education.

- P4: Maximize the underachievement of increasing men power in administration.

- D4: Minimize the over achievement of increasing men power in administration.

- P5: Maximize the underachievement of number of school and college.

- D5: Minimize the overachievement of number of school and colleges. 
- P6: Maximize the underachievement of providing constructive alignment.

- D6: Minimize the overachievement of providing constructive alignment.

- $\mathrm{Wi}^{+}$: Positive weights that shows the preference of decision makers regarding the importance of each goal.

- $\mathrm{Wi}^{-}$: Negative weights according to the preference of decision makers associated with each goal.

- Aij: coefficients of decision variable.

C. Model formulation by weighted goal programming method Minimize $\mathrm{Z}=\sum\left(\mathrm{Wi}^{+} \mathrm{Pi}+\mathrm{Wi}^{-} \mathrm{Di}\right)$, where $\mathrm{i}=1,2, \ldots, 6$

Subject to the constraints:

$\sum$ Aij $X j+P i-D i=B i$ where $i=1,2,3 \ldots 6$ and $j=1,2$

With Non negative restriction

$\mathrm{Xi}, \mathrm{Di}, \mathrm{Pi} \geq 0$ for all i, $\mathrm{j}$

An illustrative example:

For improving the system of education, government needs professors and educational advisor. For set up of new syllabus organization needs 4 professors and 2 educational advisors. The total days for syllabus setup should be less than 15. For improving the quality of education, organization needs 5 professors and 4 educational advisors. The total number of days should be more than 7 . For increasing the number of men power, organization needs 2 professors and 3 educational advisors for selection. The day of selection should be less than 10.

Let

Goal G1 = goal to setup new syllabus.

Goal G2 = goal to improve education quality.

Goal G3 = goal to increase men power in the panel of syllabus set up.

Formulation of goal programming:

Let,

- $\quad \mathrm{x}=$ time taken by professor for each work.

- $\quad y=$ time taken by educational advisor for each work.

- $\quad$ P1 =Minimize the underachievement of time for the setup of new syllabus.

- $\quad$ D1= Maximize the overachievement of time for the setup of new syllabus.

- $\quad$ P2 = Maximize the underachievement of time for improving education quality.

- $\quad$ D2= Minimize the overachievement of time for improving education quality.

- $\quad$ P3 = Minimize the overachievement of days for selection process of men power in panel of syllabus setup.

- $\quad$ D3= Maximize the underachievement of days for selection process of men power in panel of syllabus setup.
Mathematical model formulation of weighted goal programming problem on syllabus planning

Minimize $\mathrm{Z}=\sum\left(\mathrm{Wi}^{+} \mathrm{Pi}+\mathrm{Wi}^{-} \mathrm{Di}\right)$

where, $\mathrm{i}=1,2,3$

Subject to constraints

$4 \mathrm{x}+2 \mathrm{y}+\mathrm{P} 1-\mathrm{D} 1=15$

$5 \mathrm{x}+4 \mathrm{y}+\mathrm{P} 2-\mathrm{D} 2=7$

$2 \mathrm{x}+3 \mathrm{y}+\mathrm{P} 3-\mathrm{D} 3=10$

With Non negative restrictions

$\mathrm{x}, \mathrm{y}, \mathrm{Pi}, \mathrm{Di} \geq 0$

\section{Result}

With the use of method of solving multiple objective weighted goal programming, we achieve the feasible solution to obtain the advance education system and reduce the complexity of management in decision making. Since every system faces both underachievement and overachievement, thus this method reduces completely the complexity by taking both at the same time.

\section{Conclusion}

Achievement of goals in the setup of syllabus to improve the education system helps to boost the economy of the country. It will help students in selecting their syllabus according to their future concern and also help the industries to select the optimal men power having advance knowledge in the respective field of work.

\section{Acknowledgement}

First I like to thank my Mom, Dad, husband and my father in law for there continues financial and moral support. I like to thank my supervisor Dr. Rajesh Kumar Tiwari (Head university department of Mathematics BBMKU, Dhanbad) for their guidelines without whom I am not able to write this paper. My sincere thanks to Dr. Shailendra Kumar Sinha (Head university department of zoology BBMKU, Dhanbad) for his consistent support and guidelines to write a research paper. I would also like to thanks Dr. Shiv Prasad (Assistant professor University department of mathematics BBMKU, Dhanbad) for the review.

\section{References}

[1] S. Kalavathy, "Operation research 4th edition," Goal programming, pp. 169-180, 2003.

[2] J. K. Sharma, "Operation research (theory and application) 4th edition," Goal programming, pp. 239-258, 2009.

[3] D. H. Wagner, "American mathematical monthly," Mathematician in operation research consulting, vol. 3, no. 9, pp. 895-905, Nov.1975.

[4] Waynel. Winston, "O. R. application and algorithm 4th edition", The simplex algorithm and goal programming, pp. 127-172, 2004.

[5] W. L. Sartoris and M. L. Spruill, "Financial Management Association international," Goal programming and working capital management, vol. 3, no. 1, pp. 67-74, 1974. 